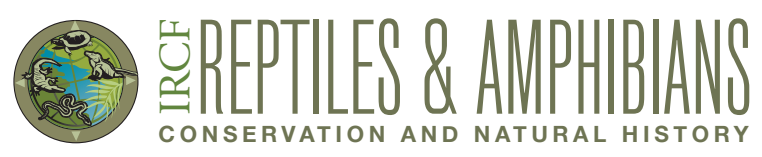

\title{
Predation on a Common Water Monitor (Varanus salvator) by a Common Myna (Acridotheres tristis) in Malda, West Bengal, India
}

\author{
Rakesh Kumar Mohalik ${ }^{1}$, Khan Ashaharraza ${ }^{2}$, and Soham Chakraborty ${ }^{3}$ \\ ${ }^{1}$ Keonjhar Wildlife Division, Anandapur-758021, Keonjhar, Odisha, India (mohalikrakeshkumar@gmail.com) \\ ${ }_{2}^{2}$ Department of Wildlife and Biodiversity Conservation, North Orissa University, Baripada-757003, Odisha, India (ashaharrazakhan@gmail.com) \\ ${ }^{3}$ Chandrail Primary School, Nalagola-733124, Malda, West Bengal, India
}

$\mathrm{T}$

he Common Myna (Acridotheres tristis) is a cosmopolitan, widespread species in the Indian subcontinent (Ali and Ripley 2001; Grimmett et al. 2006). Like all south Asian sturnids (starlings and mynas), the species is omnivorous and a dietary generalist in nature (Ali and Ripley
2001). The known diet of Common Mynas includes insects, arachnids, crustaceans, small mammals, seeds, grain, fruits, and human garbage (Mason 1911; Mathew et al. 1978). However, Common Mynas rarely attempt predation on reptiles (Dhamankar 2003).

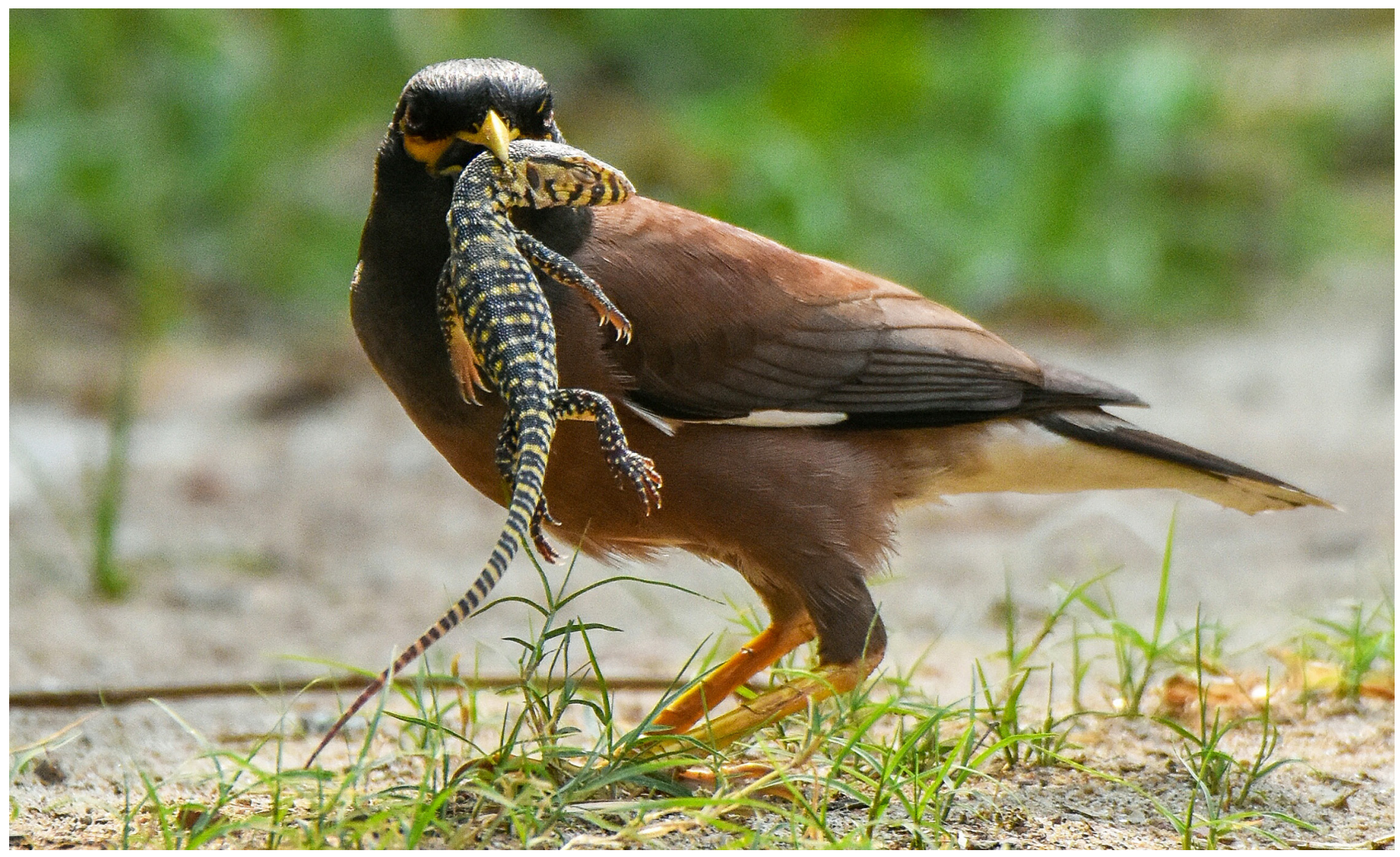

Fig. 1. A juvenile Common Water Monitor (Varanus salvator) taken by a Common Myna (Acridotheres tristis) in Malda, West Bengal, India. Photograph by Soham Chakraborty. 
On 27 September 2019, we observed an adult Common Myna calling vigorously and making multiple attempts to catch a lizard in vegetation near a lentic seasonal pond at Nalagola $\left(25.2629^{\circ} \mathrm{N}, 88.4081^{\circ} \mathrm{E}\right)$, Malda, West Bengal, India. The bird eventually succeeded in catching the lizard (Fig. 1), which we identified as a juvenile Common Water Monitor (Varanus salvator) (Das 2010). The varanid continued struggling although the myna pecked it repeatedly without losing its hold and swung it vigorously in an apparent effort to break its spine. This continued for 10-15 min before the bird flew away with the lizard into the forest and disappeared from our view.

\section{Literature Cited}

Ali, S. and S.D. Ripley. 2001. Handbook of the Birds of India and Pakistan, Volume 5 Larks to the Grey Hypocolius. Oxford University Press, New Delhi, India.

Das, I. 2010. Field Guide to the Reptiles of South-East Asia. New Holland Publishers Ltd., London, UK.

Dhamankar, A. 2003. Myna feeding on trinket snake. Newsletter for Birdwatchers 43(5): 74 .

Grimmett, R., C. Inskipp, and T. Inskipp. 2006. Birds of the Indian Subcontinent. Oxford University Press, London, UK.

Mason, C.W. 1911. The Food of Birds in India. Entomological Series Vol. III. Memoirs of the Department of Agriculture in India, Calcutta, India.

Mathew, D.N., T.C. Narendran, and V.J. Zacharias. 1978. A comparative study of the feeding habits of certain species of Indian birds affecting agriculture. Journal of the Bombay Natural History Society 75: 1178-1197. 